Стовбан Микола Петрович кандидат медичних наук, доцент, заступник генерального директора, комунальне некомерційне підприємство "ІваноФранківська обласна клінічна інфекційна лікарня Івано-Франківської Обласної Ради", вул. Гетьмана Сагайдачного, 66, Івано-Франківськ, 76000, тел.: (0342) 5049-06, https://orcid.org/0000-0002-6576-7494

Завада Оксана Григорівна завідувач навчальним кабінетом кафедри ракетних військ факультету ракетних військ і артилерії, Національна академія сухопутних військ імені Петра Сагайдачного, вул. Героїв Майдану, 32, Львів, 79026, тел.: (0322) 38-65-34, https://orcid.org/0000-0002-6296-5831

\title{
РЕТРОСПЕКТИВНИЙ АНАЛІЗ ОСНОВНИХ ПОКАЗНИКІВ ЕФЕКТИВНОСТІ ДІЯЛЬНОСТІ КОСІВСЬКОЇ ЦРЛ ЗА ПЕРІОД 2014-2018 РОКІВ
}

Анотація. В статті проведено ретроспективний аналіз основних показників ефективності діяльності Косівської ЦРЛ. Запропоновано авторську методику розрахунку показників ефективності діяльності лікарні за складовими медичної, соціальної та економічної ефективності. Обгрунтовано причини низького рівня ефективності діяльності Косівської ЦРЛ та запропоновано шляхи її підвищення.

Метою статті $\epsilon$ проведення ретроспективного аналізу ефективності діяльності Косівської центральної районної лікарні задля визначення основних проблем діяльності місцевих лікувальних закладів та формування науковообгрунтованих пропозицій щодо удосконалення медичної системи у новостворених об'єднаних територіальних громадах.

Методи дослідження. В статті використано загальнонаукові методи дослідження, зокрема: аналізу синтезу - при дослідженні наукової літератури та визначення ефективності діяльності Косівської ЦРЛ; економіко-статистичного аналізу і порівняння - при розрахунку показників медичної, соціальної та економічної ефективності діяльності Косівської ЦРЛ; узагальнення - при розробці рекомендацій щодо підвищення ефективності діяльності Косівської ЦРЛ.

Результати: розроблено авторську методику розрахунку показників оцінки медичної, соціальної та економічної ефективності діяльності Косівської ЦРЛ. Проведено ретроспективний аналіз ефективності діяльності Косівської ЦРЛ, що дало змогу констатувати низький рівень ефективності, який сформувався під впливом факторів не залежних від діяльності самої лікарні. Обгрунтовано необхідність запровадження платних медичних послуг та їх реалізації Косівською 
ЦРЛ, розвиток державно-приватного партнерства та механізм придбання діагностичного обладнання для реалізації програм 3 комплексної діагностики здоров'я населення Косівської міської об’єднаної територіальної громади.

Ключові слова: ефективність діяльності лікарні, медична ефективність, соціальна ефективність, економічна ефективність, Косівська ЦРЛ, охорона здоров'я.

Stovban Mykola Petrovych Candidate of Medical Sciences, Associate Professor, Deputy General director of communal non-profit enterprise "Ivano-Frankivsk regional clinical Infectious Diseases Hospital of Ivano-Frankivsk Regional Council", Hetman Sagaidachnoho St., 66, Ivano-Frankivsk, 76000, tel.: (0342) 50-49-06, https: //orcid.org/0000-0002-6576-7494

Zavada Oksana Hryhorivna Chief of Department of Rocket Forces of Faculty of Rocket Forces and Artillery of Petro Sahaidachny National Academy of Ground Forces, Master of Public Administration, Heroiv Maidanu St., 32, Lviv, 79026, tel .: (0322) 38-6534, https://orcid.org/0000-0002-6296-5831, https: //orcid.org/0000-0002-6296-5831

\section{RETROSPECTIVE ANALYSIS OF THE MAIN PERFORMANCE INDICATORS OF THE KOSIV CDH FOR THE PERIOD 2014-2018}

Abstract. The article provides a retrospective analysis of the main performance indicators of the Kosiv CDH. The author's method of calculation of indicators of efficiency of activity of hospital on components of medical, social and economic efficiency is offered. The reasons for the low level of efficiency of the Kosiv CDH are substantiated and ways to increase it are suggested.

The purpose of the article is to conduct a retrospective analysis of the effectiveness of the Kosiv Central District Hospital to identify the main problems of local medical institutions and the formation of scientifically sound proposals for improving the medical system in the newly formed united territorial communities.

Research methods. The article uses general scientific research methods, in particular: synthesis analysis - in the study of scientific literature and determining the effectiveness of the Kosiv CDH; economic and statistical analysis and comparison when calculating the indicators of medical, social and economic efficiency of the Kosiv $\mathrm{CDH}$; generalization - in the development of recommendations for improving the efficiency of the Kosiv CDH.

Results: the author's method of calculation of indicators of assessment of medical, social and economic efficiency of activity of the Kosiv $\mathrm{CDH}$ is developed. A retrospective analysis of the efficiency of the Kosiv $\mathrm{CDH}$ was conducted, which allowed to state the low level of efficiency, which was formed under the influence of factors independent of the activity of the hospital itself. The necessity of introduction of paid medical services and their realization by the Kosiv $\mathrm{CDH}$, development of public- 
private partnership and mechanism for purchasing diagnostic equipment for the implementation of programs for comprehensive diagnostics of public health of the Kosiv city united territorial community are substantiated.

Keywords: hospital efficiency, medical efficiency, social efficiency, economic efficiency, Kosiv $\mathrm{CDH}$, health care.

Постановка проблеми. Діяльність закладів охорони здоров'я в Україні та всієї медичної системи досить часто піддається гострій критиці збоку пацієнтів і пересічних громадян щодо неякісних медичних послуг. Якість медичних послуг, медичного обслуговування та медичної інфраструктури безумовно залежить від принципів побудови медичної системи в Україні та розвитку національної економіки, адже без фінансового підгрунтя досить важко створити ефективну медичну систему і забезпечити ефективну діяльність всіх лікувальних закладів.

Пандемія COVID-19 досить добре акцентувала увагу на основних проблемах охорони здоров'я в Україні, а особливо на проблемах діяльності лікувальних закладах в колишніх адміністративних районах областей нашої держави. Зокрема основною проблемою $є$ фактична відсутність лікувальної інфраструктури, медичного обладнання, кваліфікованого персоналу, гідної оплати праці та соціального захисту медичних працівників. Лікувальна інфраструктура, яка об'єднує в собі не лише приміщення лікарень, але й медичне обладнання та матеріально-технічне забезпечення швидкої медичної допомоги в зв'язку 3 недофінансуванням галузі 3 державного і місцевих бюджетів в переважній більшості центральних районних лікарень перебуває у незадовільному стані, а більшість медичного обладнання залишилося у спадок від колишнього Радянського Союзу. Відсутність системи медичного страхування та системи державно-приватного партнерства в галузі медицини вирішення основних проблеми медичного забезпечення лікування коронавірусу в Україні поклало на плечі волонтерів, благодійників і меценатів. Тому проведені реформи первинної і вторинної ланки медицини повинні були врахувати необхідність розвитку державно-приватного партнерства в медичній галузі України, а також затвердити платні медичні послуги, які можуть надавати центральні районні лікарні для забезпечення їх якості, а головне - для власного збереження (адже багато центральних районних лікарень перебувають на межі закриття).

Аналіз останніх досліджень і публікацій. Питання ефективної роботи медичних закладів здебільшого порушено на побутовому рівні, однак в науковому плані цій проблематиці приділено вкрай мало уваги, зокрема це стосується досліджень діяльності центральних районних лікарень, які мать обмежені фінансові ресурси для забезпечення ефективного медичного 
обслуговування мешканців новостворених об'єднаних територіальних громад. Так, серед вітчизняних науковців, які присвятили свої праці дослідженню ефективності діяльності закладів охорони здоров'я можна виокремити таких вчених як: Говорко О. В. [2]; Карамишев Д. В., Удовиченко Н. М. [3]; Мартинюк О. А. [4]; Мокрицька А.Б. [5]; Панчишин Н. Я., Смірнова В. Л. [7]; Шведа Ю.І. [9] та інші. Однак, перелічені науковці основну увагу в своїх дослідженнях зосереджують на макрорівні, тобто на ефективності всієї системи охорони здоров'я України, про те, на наш погляд, враховуючи процеси децентралізації та медичної реформи, наукового аналізу потребують питання ефективності роботи центральних районних лікарень, як головних лікувальних закладів багатьох новостворених об'єднаних територіальних громад. Адже, отримавши на баланси центральні районні лікарні, об’єднані територіальні громади використовуючи внутрішні фінансові ресурси, субвенції з державного бюджету та інновації в сфері державно-приватного партнерства можуть суттєво підвищити ефективність діяльності центральних районних лікарень.

Тому метою цієї статті є проведення ретроспективного аналізу ефективності діяльності Косівської центральної районної лікарні задля визначення основних проблем діяльності місцевих лікувальних закладів та формування науковообгрунтованих пропозицій щодо удосконалення медичної системи у новостворених об’єднаних територіальних громадах.

Виклад основного матеріалу. Оцінка ефективності діяльності центральної районної лікарні чи будь-якого іншого закладу охорони здоров'я неможлива без визначення сутнісних ознак поняття ефективності діяльності лікарні, адже на відміну від підприємств реального сектору економіки не залежно від форм власності, ефективність закладу охорони здоров’я має значно ширший підтекст.

В науковій літературі немає однозначного підходу до визначення сутності ефективності діяльності лікарні, однак переважна більшість науковців схиляється до того, що сутність поняття ефективність діяльності лікарні включає в себе тріаду таких складових як: медична ефективність, соціальна ефективність та економічна ефективність.

Так, зокрема Назарко С. О. [6] виділяє такі складові ефективності діяльності закладу охорони здоров'я: медична ефективність - тобто здатність якнайповніше задовольняти потреби споживачів шляхом надання повного спектру високоякісних медичних послуг; адміністративна ефективність - передусім ефективність адміністративного, фінансового, кадрового, інформаційного, комунікаційного менеджменту в управлінні установою, ii підрозділами, ресурсами; економічна ефективність - надавати медичну допомогу таким чином, щоб максимізувати використання ресурсів та уникнути марних витрат. 
Аналізуючи запропоновані складові ефективності діяльності закладу охорони здоров'я Назарком С.О., зауважимо, що такі пропозиції $є$ слушними, однак їх досить важко оцінити на практиці і зробити відповідний висновок щодо ефективності діяльності лікарні. Так, не зрозуміло, яким чином визначити максимальну задоволеність потреб споживачів якісними медичними послугами. Таких показників в офіційній статистиці України, області чи району не існує. Однак, у якості пропозиції запропонуємо проведення щорічних опитувань пацієнтів центральних районних лікарень та інших лікувальних закладів на предмет задоволеності медичними послугами.

Щодо адміністративної ефективності, то пропозиція також є слушною, однак зважаючи на те, що центральні районні лікарні перебувають у комунальній власності та $є$ некомерційними організаціями, ефективність менеджменту залежить від процедури призначення керівництва лікарні органами місцевого самоврядування.

Економічна ефективність діяльності лікарні, на наш погляд, має дещо ширше поняття, ніж запропоновано Назарком С.О., адже будучи некомерційною організацією та працюючи в умовах медично системи на засадах безоплатного медичного обслуговування лікарня не отримує доходи за надання медичних послуг населенню. Тобто центральні лікарні в Україні працюють, фактично, за межами медичного ринку, де вартість послуг визначається адміністративно і оплачується 3 державного і місцевих бюджетів за кошти платників податків не залежно від рівня якості медичної послуги.

Український дослідник Говорко О.В., серед елементів ефективності закладів охорони здоров'я, також виділяє елемент медичної ефективності, під якою розуміє ступінь досягнення клінічного ефекту. На рівні закладів охорони здоров'я та галузі в цілому медична ефективність вимірюється безліччю специфічних показників: питома вага вилікуваних хворих, зменшення випадків переходу захворювання в хронічну форму, зниження рівня захворюваності населення [2, с. 93]. На думку Говорка О.В., соціальна ефективність, в свою чергу, являється ступенем досягнення соціального результату. Наприклад, збільшення тривалості життя населення, зниження рівня показників смертності та інвалідності, задоволеність суспільства в цілому системою надання медичної допомоги. Окрім цього, під економічною ефективністю автор розуміє співвідношенням одержаних результатів до здійснених витрат. Розрахунок економічної ефективності пов'язаний з пошуком найбільш економного використання наявних ресурсів [2, с. 94].

Аналізуючи наявні підходи до визначення сутності ефективності діяльності лікарень та інших закладів охорони здоров'я $[2 ; 7 ; 3 ; 6]$ зауважимо, що теоретично можемо виокремити велику кількість показників ефективності діяльності лікарні, однак для отримання наукового результату та результату для органів місцевого 
самоврядування, на наш погляд, показники ефективності діяльності повинні визначатися за принципами вимірності, прогнозованості та значущості.

Суть принципу вимірності полягає в тому, що пропонований показник діяльності лікарні повинен бути вимірним, тобто мати конкретне кількісне значення в абсолютному чи відносному значенні. Окрім цього, цифрові дані для обчислення значення даного показника повинні бути доступними для дослідника.

Принцип прогнозованості передбачає змогу прогнозування майбутньої динаміки того чи іншого показника, оскільки однією із основних вимог до управління тим чи іншим процесом є його прогнозованість.

Принцип значущості передбачає врахування лише тих показників, які $\epsilon$ значущими для конкретного об’єкта дослідження та дозволяє виокремити основні проблеми чи тенденції розвитку об'єкта дослідження, в нашому випадку Косівської центральної районної лікарні.

Таким чином, з цих позицій ми також виділимо медичну ефективність роботи лікарні, однак на відміну від існуючих підходів, які акцентують увагу на якості медичної послуги, ми пропонуємо зосередити увагу на таких показниках як: рівень захворюваності в регіоні; рівень смертності; досягнення результативності діагностики і лікування захворювань. Такі показники нами обрано 3 позицій їх вимірності і значущості для діяльності Косівської ЦРЛ, адже цей лікувальний заклад після утворення Косівської міської територіальної громади став основним лікувальним закладом для чотирнадцяти населених пунктів, а отже враховуючи принципи децентралізацї та стратегію розвитку Косівської міської територіальної громади, Косівська ЦРЛ є основним закладом охорони здоров’я в регіоні. Відтак, діяльність Косівської ЦРЛ повинна бути спрямованою не лише на лікування громадян у випадку їх звернень, але й на проведення профілактично-діагностичних заходів в кожному населеному пункті громади.

Враховуючи ментальність українців та низький рівень довіри до закладів охорони здоров'я, зауважимо, що 90\% громадян самостійно не відвідують лікувальні заклади з метою діагностики власного здоров'я, а тому обов'язкова діагностика населення на предмет захворюваності і здорового способу життя $\epsilon$ запорукою довготривалості життя населення громади. Таким чином динаміка рівня захворюваності та смертності в регіоні можуть бути тими показниками, які відображають ефективність роботи Косівської ЦРЛ в напрямку своєчасного виявлення та попередження захворювань серед населення громади. При цьому, зауважимо, що необхідні показники розраховуються статистичними управлінням області та $є$ доступними для дослідників. Разом 3 цим, зауважимо, що органи місцевого самоврядування з метою аудиту якості медичних послуг Косівської ЦРЛ можуть проводити щорічне соціологічне дослідження, яке дозволить зрозуміти рівень досягнення результативності діагности і лікування захворювань в громаді, а також задоволеність населення якістю медичних послуг. Запропоновані нами 
показники оцінки ефективності діяльності лікарні згрупуємо на рисунку 1.

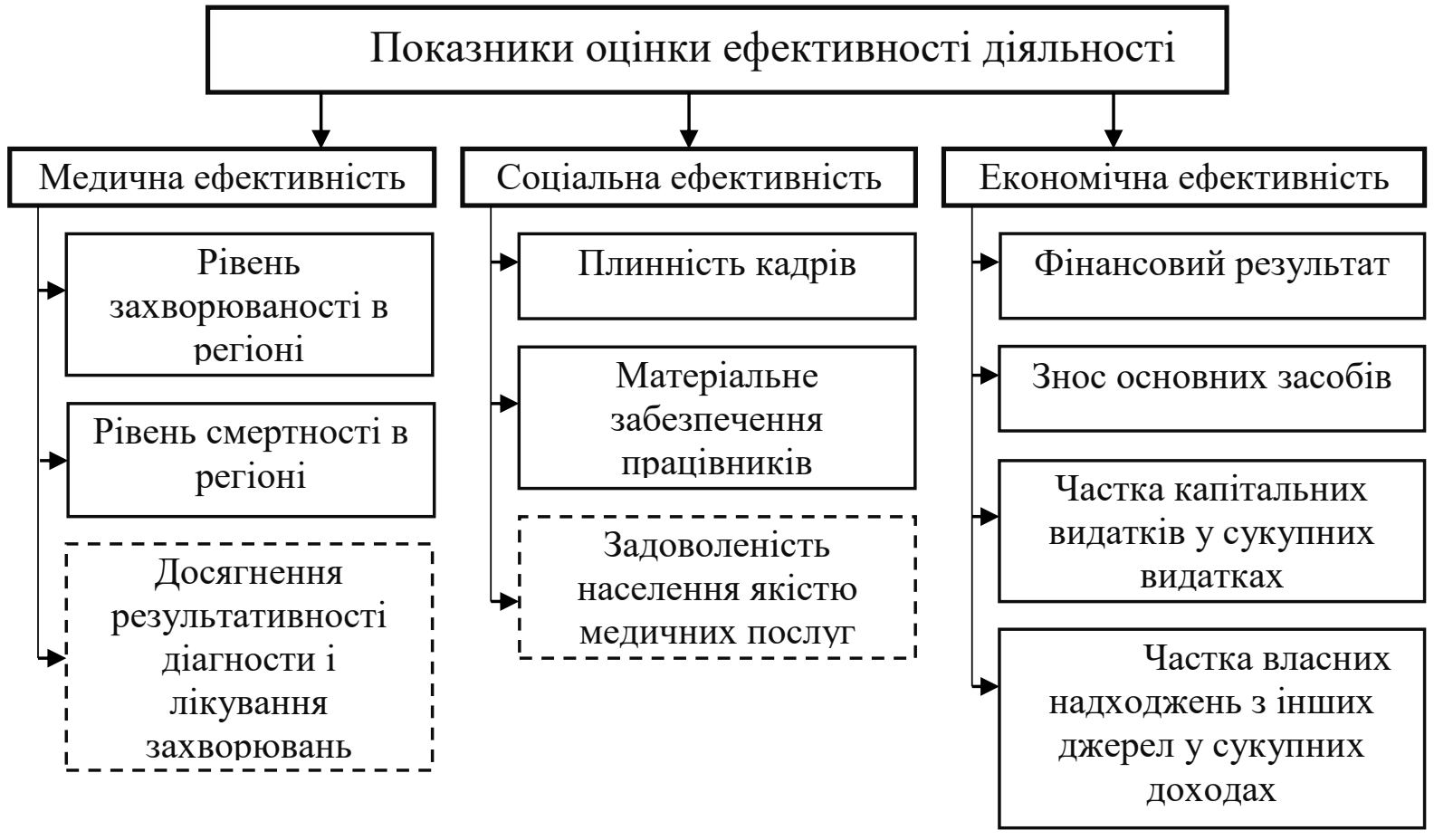

Pис. 1. Показники оцінки ефективності діяльності лікарні*

*Власна розробка автора

Соціальна ефективність роботи лікарні, на наш погляд, є дещо ширшим поняттям, ніж те, що обгрунтовано в працях $[2 ; 7 ; 3 ; 6]$, адже соціальний ефект від діяльності лікарні спрямований не лише на пацієнтів, але й на працівників. Відтак, основними показниками, які відображатимуть соціальну ефективність діяльності лікарні будуть такі: плинність кадрів; матеріальне забезпечення працівників; задоволеність населення якістю медичних послуг. Перші два показники присутні в офіційній статистиці, а щодо рівня задоволеності населення якістю медичних послуг, то доцільно організувати щорічне статистичне опитування на рівні Косівської міської об'єднаної територіальної громади.

Оцінка економічної ефективності Косівської центральної районної лікарні також має свої особливості, адже районна лікарня є комунальним некомерційним підприємством, тому потрібно використовувати дещо інші підходи до оцінки економічної ефективності на відміну від підприємств реального сектору. Отже, одним із основних показників економічної ефективності є фінансовий результат, однак оцінка фінансового результату повинна відбуватися не 3 точки зору ринкового аспекту, де визначаються затрати на надання медичних послуг i отриманий дохід, а з точки зору перевищення доходів лікарні над витратами. Цей показник показує необхідність пошуку джерел для дофінансування лікарні у 
випадку негативного фінансового результату, або у випадку позитивного фінансового результату - надлишок коштів, який можна спрямувати на покращення матеріально-технічного забезпечення лікарні.

Важливим показником економічної ефективності діяльності лікарні $\epsilon$ коефіцієнт зносу основних засобів, який відображає тенденції оновлення матеріально-технічного забезпечення лікарні, а отже іiі спроможність надавати кваліфіковані медичні послуги і забезпечувати якісну медичну допомогу.

Частка капітальних видатків у сукупних видатках лікарні $\epsilon$ важливим показником 3 точки зору оцінки можливостей лікарні у сфері оновлення матеріально-технічного забезпечення, модернізації приміщень тощо.

Частка власних надходжень з інших джерел у сукупних доходах, як показник оцінки економічної ефективності діяльності лікарні свідчить про рівень залучення коштів 3 небюджетних джерел у вигляд внесків благодійників та меценатів. Окрім цього, цей показник відображає потенціал лікарні в напрямку розвитку державно-приватного партнерства і переходу до часткової реалізації платних медичних послуг.

Обгрунтувавши показники оцінки ефективності діяльності лікарні проаналізуємо ефективність діяльності Косівської центральної районної лікарні за період 2014-2018 років.

Так, що стосується медичної ефективності то, даних щодо оцінки рівня захворюваності населення Косівського району недостатньо для грунтовної оцінки, однак 3 публічних звітів голови Косівської районної державної адміністрації можна зробити висновок про погіршення динаміки захворюваності населення у 2016-2017 роках. Так, захворюваність населення Косівського району на 10000 населення зросла з 523,7 у 2016 році до 554,3 у 2017 році, а показник хворобливості виріс $з$ 1528,1до 1541,2 відповідно [8]. Такі результати можуть свідчити про недостатній рівень діагностики і попередження захворюваності серед населення збоку персоналу Косівської ЦРЛ. В силу спрямування основної суми видатків 3 державного і місцевого бюджетів на оплату заробітної плати $(85 \%)$, оплату енергоносіїв (5,5\%), оплату медикаментів та харчування $(4,5 \%)$ [8], спостерігається нестача коштів на проведення комплексної діагностики здоров'я населення Косівського району, а зараз Косівської міської об'єднаної територіальної громади. Косівська ЦРЛ не має власних ресурсів для проведення масової комплексної діагностики здоров'я населення, адже не реалізує платні медичні послуги у зв'язку із особливостями розвитку медицини в Україні. Тому 3 цих причин медичну ефективність роботи Косівської ЦРЛ слід визнати незадовільно. Результати медичної ефективності також відображає динаміка смертності населення Косівського району, яка є досить високою в порівнянні 3 рівнем народжуваності (рис. 2). 


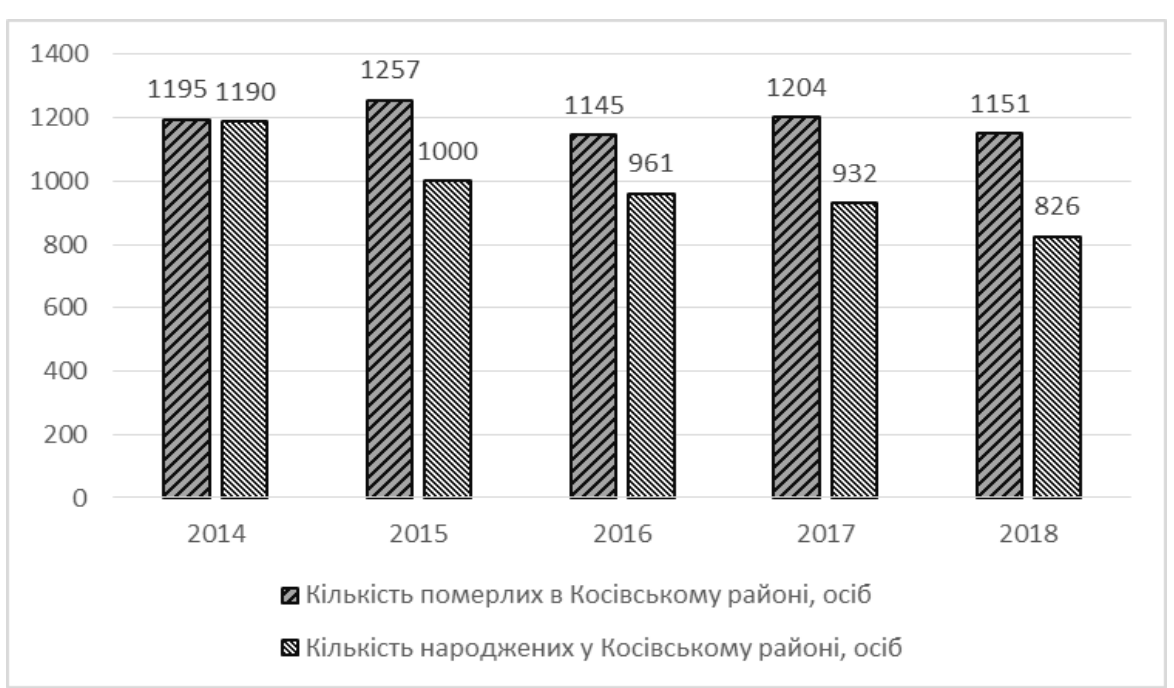

Рис. 2. Демографічна ситуація в Косівському районі Івано-Франківської області у 2014-2018 роках*

*Розраховано автором за даними Відділу статистики Косівської районної державної адміністрації

Як свідчать дані рисунку 2 динаміка смертності в Косівському районі ІваноФранківської області має негативну тенденцію, що окрім різних соціальних факторів $є$ наслідком незадовільного медичного обслуговування населення в частині проведення комплексної діагностики здоров'я населення і своєчасного виявлення захворюваності.

За свідченням Косівської районної державної адміністрації (станом на 2017 рік) в структурі смертності жителів району перше місце займають хвороби органів кровообігу: 74,1\%; на другому місці онкологічні хвороби $10,8 \%$; третє місце займають хвороби органів травлення - 3,9\% [8]. Тому саме на діагностику цих хвороб Косівській ЦРЛ варто звернути увагу в майбутньому.

Щодо соціальної ефективності, то тенденції в цій сфері також $\epsilon$ негативними, адже кількість працівників Косівської ЦРЛ впродовж 2014-2018 років поступово зменшується (табл. 1), а плинність кадрів $є$ доволі високою.

Таблиия 1

Деякі показники плинності кадрів Косівської ЦРЛ у 20144-2018 роках*

\begin{tabular}{|l|l|l|l|l|l|}
\hline & 2014 & 2015 & 2016 & 2017 & 2018 \\
\hline Прийнято працівників, осіб & 94 & 77 & 64 & 11 & 16 \\
\hline Вибуло працівників, осіб & 68 & 87 & 78 & 9 & 31 \\
\hline $\begin{array}{l}\text { Облікова кількість штатних } \\
\text { працівників на кінець звітного } \\
\text { періоду, осіб }\end{array}$ & 1152 & 1142 & 1128 & 1112 & 860 \\
\hline Коефіцієнт плинності кадрів,\% & 5,9 & 7,6 & 6,9 & 0,8 & 3,6 \\
\hline
\end{tabular}

*Розраховано автором за даними Відділу статистики Косівської районної державної адміністрації 
Дані таблиці 1 свідчать про досить суттєве зменшення чисельності працівників Косівської ЦРЛ у 2018 році, адже кількість працівників зменшилася на 252 особи, що свідчить про результати медичної реформи в Україні, адже до цього періоду, щорічне зменшення чисельності працівників лікарні складало 1020 осіб.

Зменшення чисельності працівників Косівської ЦРЛ безумовно негативно позначається на їх якісному складі, на рівні обслуговування пацієнтів на загальній корпоративній стабільності лікарні. Коефіцієнт плинності кадрів у 2014-2016 роках також був порівняно високим. Такі тенденції в неостанню чергу зумовлені низьким рівнем матеріального забезпечення працівників лікарні, середня заробітна плата яких є нижчою, ніж середня заробітна плата в цілому по Косівському районі на 20-30\%. При цьому Косівська ЦРЛ не має змоги збільшити оплату праці працівників за рахунок надбавок і премій, адже не отримує достатньої кількості власних надходжень не 3 позабюджетних джерел фінансування.

Особливу увагу варто звернути на показники економічної ефективності роботи Косівської ЦРЛ (рис. 3). Як свідчать дані рисунку 3, фінансовий результат діяльності Косівської ЦРЛ має негативну тенденцію, а це свідчить, що потреби лікарні недофінансовані у 2014 році на 355 тис. грн., у 2016 році на 918 тис. грн, а у 2017 році на 2 млн. 143 тис. грн. Такі тенденції пов'язані з тим, що Косівська ЦРЛ $є$ комунальним некомерційним підприємством, яке не має змоги розширити самофінансування за рахунок комерціалізації певних ланок своєї діяльності.

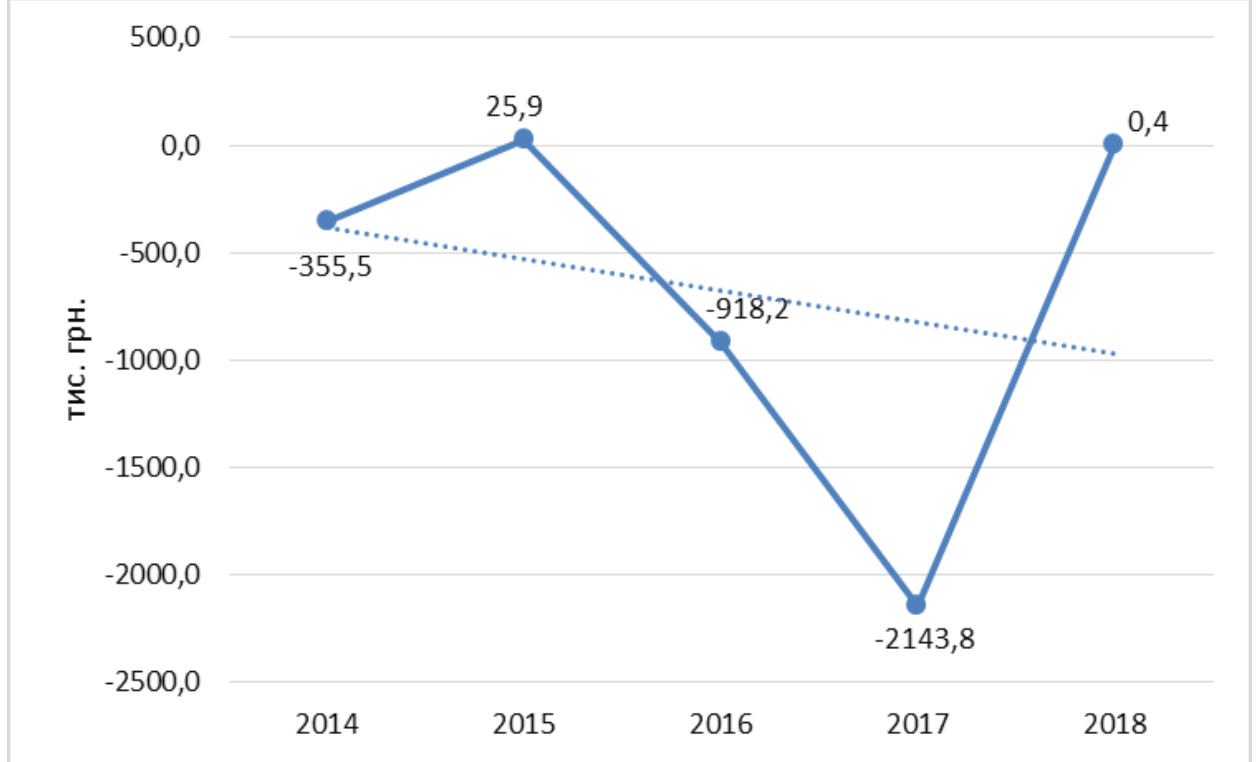

Pис. 3 Динаміка фінансового результату Косівської ЦРЛ у 2014-2018 роках* * Розраховано автором за даними Відділу статистики Косівської районної державної адміністрації

Досить негативні тенденції в частині економічної ефективності Косівської ЦРЛ відображає показник зносу основних фондів (рис. 4). 
Журнал « Науқові інноващї та передові технологї»

(Серія «Держсавне управління», Серія «Право»,

Серія «Економіка», Серія «Психологія», Серія «Педагогіка»)

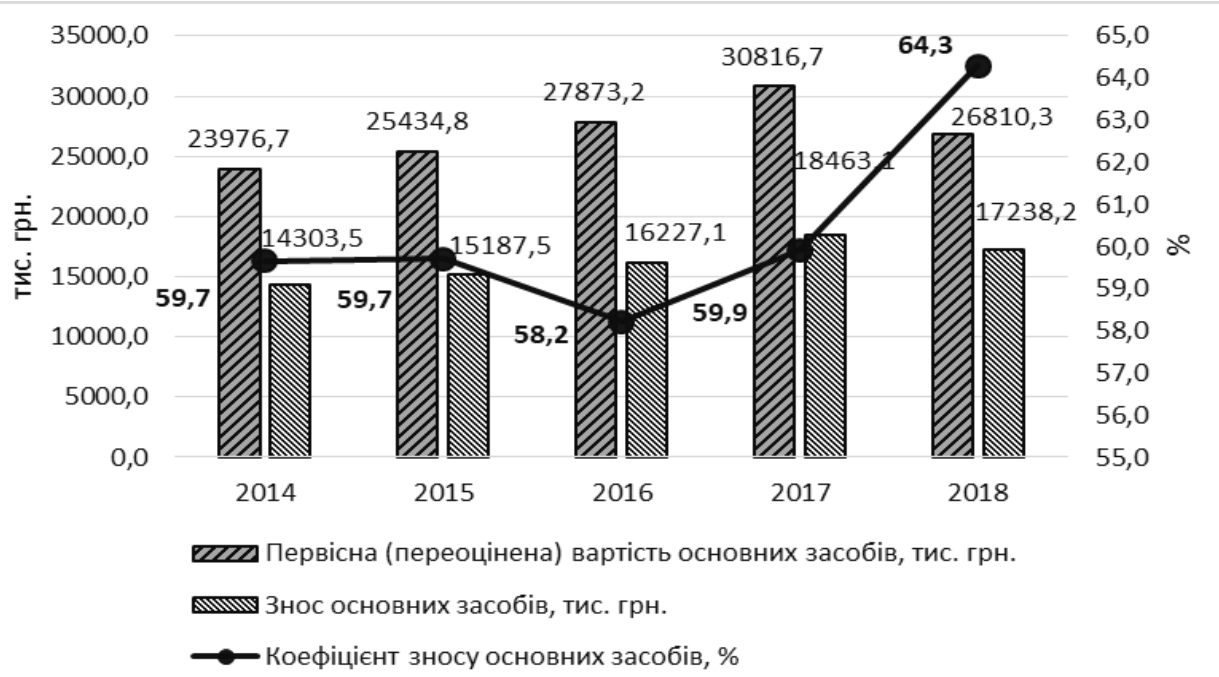

Pис. 4. Динаміка показників зносу основних засобів Косівської ЦРЛу 2014-2018 роках

*Розраховано автором за даними Відділу статистики Косівської районної державної адміністрації

Як свідчать дані рисунку 4 коефіцієнт зносу основних засобів в Косівській ЦРЛ відображає, фактично, катастрофічну ситуацію 3 розвитком медичної інфраструктури, адже станом на 2018 рік 64\% основних засобів лікарні зношені. Такі тенденції, не наш погляд, суттєво обмежують можливості Косівської ЦРЛ реалізувати свої функції в сфері надання якісних медичних послуг, адже зношеність медичного обладнання та його моральне старіння не дозволяє цього зробити.

Показник частки власних надходжень 3 інших джерел у доходах Косівської ЦРЛ також свідчить про негативні тенденції економічної ефективності, адже в 2018 році таких доходів лікарня не отримала (рис. 5).

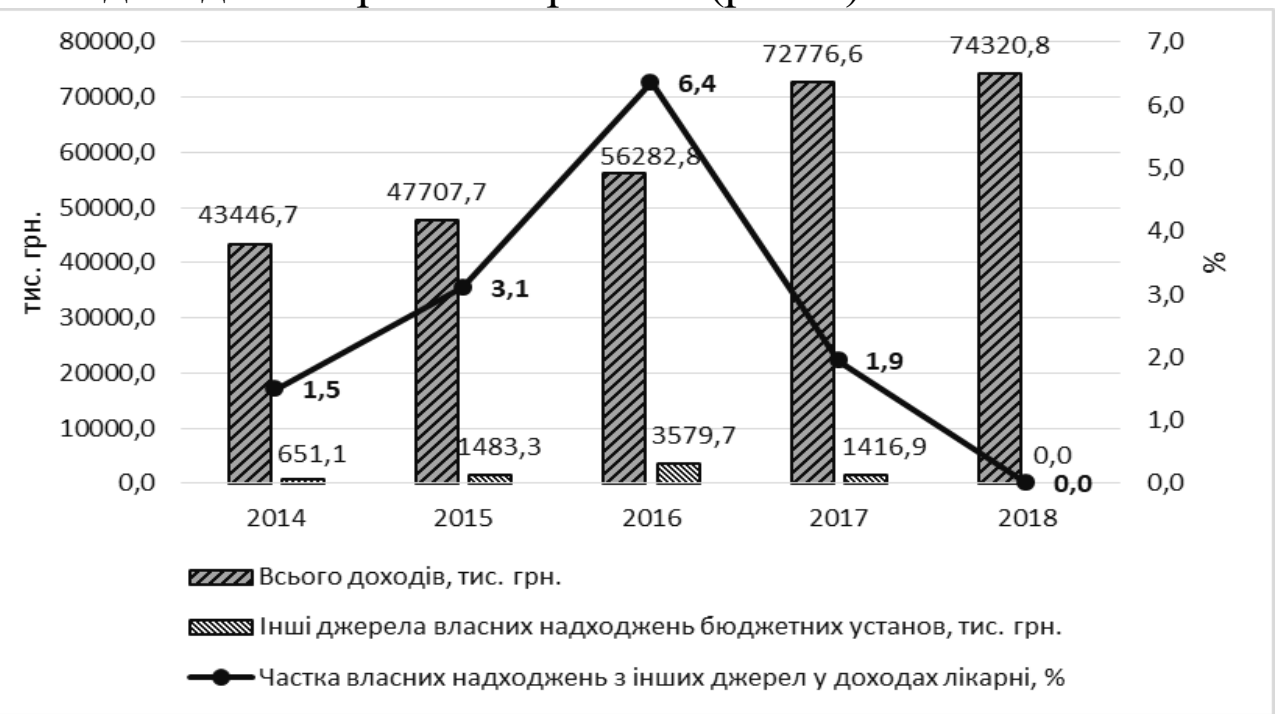

Pис. 5. Динаміка частки власних надходжень з інших джерел в доходах Косівської ЦРЛ у 2014-2018 роках

*Розраховано автором за даними Відділу статистики Косівської районної державної адміністрації 
Зниження частки небюджетних доходів Косівської ЦРЛ від благодійників та меценатів свідчить про зниження можливостей таких трансфертів на фоні економічної кризи.

Не зважаючи на незадовільні результати аналізу показників ефективності діяльності Косівської ЦРЛ у 2014-2018 роках, на наш погляд, діяльність лікарні в рамках новоствореної Косівської міської об'єднаної територіальної громади відкриває широкі перспективи для підвищення ії ефективності.

3 огляду на можливості від децентралізації владних повноважень та фінансових можливостей запропонуємо декілька напрямків підвищення ефективності діяльності Косівської ЦРЛ.

По-перше, затвердження переліку платних медичних послуг для населення Косівської міської об'єднаної територіальної громади.

Варто визнати, що безкоштовної медицини в Україні не існує. Та ситуація, яка $є$ сьогодні лише уповільнює розвиток вітчизняної медичної галузі. Тому на рівні ОТГ доцільно офіційно затвердити перелік платних медичних послуг і розмістити їх на офіційному сайті лікарні, а також на відповідних інформаційних стендах в приміщенні Косівської ЦРЛ. В такому випадку пацієнт буде знати, яку суму коштів йому необхідно зібрати для проведення тієї чи іншої операції чи лікування. Офіційна оплата за медичні послуги через механізм державноприватного партнерства дозволить пацієнтам контролювати якість послуг, мати відповідний захист у суді у випадку неякісного надання медичної послуги, а лікарні - акумулювати фонд коштів для оновлення основних фондів, закупівлі новітнього медичного обладнання, а також офіційних доплат працівникам, що дозволить підвищити їх соціальний захист і матеріальне забезпечення. Безумовно, платні послуги не повинні стосуватися людей похилого віку та дітей до певного віку (тут уже на розсуд громади). Запровадження платних послуг, на наш погляд, дозволить Косівській ЦРЛ швидко оновити основні засоби та стати ефективним лікувальним закладом громади.

По-друге, вирішення проблем комплексної діагностики здоров'я населення Косівської міської об 'єднаної територіальної громади.

Оскільки Косівська ЦРЛ є основним лікувальним закладом громади їй необхідно вирішити питання забезпечення комплексної діагности здоров'я населення шляхом виїзду безпосередньо в населені пункти для проведення обов'язкового медичного огляду.

Для цього, пропонуємо придбати пересувний діагностичний центр. Такий центр можна імпортувати з-за кордону за нульовим тарифом, або закупляти в Україні, вони обладнуються в нас. Комплектації таких центрів різні, на базі мікроавтобуса, автобуса i навіть на базі великогабаритної вантажівки $\epsilon$ хірургічний центр, який дозволяє зробити декілька операцій на день.

Такий діагностичний автомобіль дозволяє зробити повну діагностику здоров'я людини, адже має рентген-кабінет, оглядовий стіл-трансформер, кисневу і вакуумну маску всі необхідні інструменти, генератор живлення тощо. 
Питання, де взяти гроші? Звичайно автомобіль недешевий - його вартість приблизно 6-6,5 мільйона гривень або 240 тис. доларів США. На перший погляд непідйомна сума для лікарні.

Тому для вирішення цієї проблеми пропонуємо зареєструвати проект 3 купівлі пересувного діагностичного центру на базі автобуса на сайті Велика ідея - спільно кошт. Цей сайт дає змогу збирати кошти на проекти, в даному випадку на автомобіль. Тобто якщо кожен поповнить рахунок такого проекту на 100 грн., то для цього буде треба 65 тис. людей, а у випадку залучення меценатів, благодійників, волонтерів та діаспори кількість учасників проекту можна зменшити і за 50-60 днів отримати необхідну суму для закупівлі пересувного діагностичного центру.

Придбання такого автомобіля дозволить сформувати графік обов'язкової діагностики здоров'я всього населення громади та своєчасно проводити лікування хворих, що безумовно вплине на ефективність діяльності Косівської ЦРЛ, адже дасть смогу проводити превентивні заходи 3 підтримки здоров'я громадян, а не лікувати постфактум, після звернення громадян до лікарні, яке досить часто є вже запізнілим.

Така діагностика може бути платною послугою вартість якої розраховуватиметься з позицій затрат часу громадян на поїздку до лікарні, комплексності діагностики тощо.

Таким чином, запропоновані нами заходи можуть бути одними із варіантів підвищення ефективності діяльності Косівської ЦРЛ, покращення іiі матеріальнотехнічного забезпечення та підвищення якості медичних послуг.

Висновки. Ретроспективний аналіз ефективності діяльності Косівської ЦРЛ у 2014-2018 роках дав змогу зробити висновок про досить низький рівень такої ефективності. Однак, потрібно розуміти, що низький рівень ефективності діяльності Косівської ЦРЛ зумовлений існуючими принципами розвитку медицини в Україні, яка де-юре заснована на концепції безоплатного медичного обслуговування. Перманентні політико-економічні кризи не дають змоги державному і місцевому бюджетам в достатній мірі профінансувати діяльність лікувальних закладів, що призводить до суттєвого зносу основних фондів, а це в свою чергу, відбивається на якості медичних послуг.

Відтак, таким чином, отримавши можливості розвивати медичну сферу в умовах децентралізації органи місцевого самоврядування повинні задіяти механізми небюджетного збільшення фінансових ресурсів лікарень за рахунок впровадження платних медичних послуг. Окрім цього необхідним є купівля пересувних діагностичних центрів 3 метою реалізації програм комплексної діагностики здоров'я населення і реалізації заходів превентивної медичної допомоги. Реалізація програм державно-приватного партнерства також повинна стати одним із заходів розвитку медицини на місцях та покращення матеріальнотехнічного стану Косівської ЦРЛ.

Разом 3 тим, подальші наукові дослідження вимагають вирішення проблем 
аудиту якості надання медичних послуг центральними районними лікарнями, проведення соціологічних досліджень серед населення, що дасть змогу розробити політику розвитку охорони здоров'я та модернізувати лікарні в новостворених об’єднаних територіальних громадах.

\section{Jimepamypa:}

1. Відділ статистики Косівської районної державної адміністрації. URL: https://kosivrda.gov.ua/statystyka.html? start=300.

2. Говорко О. В. Ефективність системи забезпечення охорони здоров'я населення України. Інтелект ХХI. 2017. № 2.С. 92-97.

3. Карамишев Д. В. Удовиченко Н. М. Сутність розуміння ефективності управління системою охорони здоров'я в сучасних умовах. Державне будівниитво. 2008. № 1. URL: http://nbuv.gov.ua/UJRN/DeBu_2008_1_26.

4. Мартинюк О. А. Впровадження системи управління якістю в медичних закладах. Причорноморські економічні студї. 2016. Вип. 6. С. 75-79.

5. Мокрицька А.Б. Фінансове забезпечення охорони здоров'я України: теоретична концептуалізація та проблеми організації. Наука й економіка. 2014. 4 (36). С. 177-179.

6. Назарко С. О. Ефективне управління медичним закладом в умовах реформування системи охорони здоров'я. Електронне наукове фахове видання «Ефективна економіка». URL: http://www.economy.nayka.com.ua/pdf/1_2020/57.pdf/.

7. Панчишин Н. Я., Смірнова В. Л. Оцінка ефективності управління в системі охорони здоров’я. Вісник соиіальної гігієни та організації охорони здоров'я України. 2012. № 3. С. 57-59.

8. Публічний звіт голови Косівської районної державної адміністрації. URL: http://www.if.gov.ua/files/uploads/\%D0\%97\%D0\%B2\%D1\%96\%D1\%82\%202017\%20\%D0\%9A\%D 0\%BE\%D1\%81\%D1\%96\%D0\%B2\%D1\%81\%D1\%8C\%D0\%BA\%D0\%B0\%20\%D0\%A0\%D0\%94 $\%$ D0\%90.pdf.

9. Шведа Ю. І. Вплив конкуренції на ефективність системи охорони здоров’я України. Ефективність державного управління. 2018. Вип. 3. С. 169-180.

\section{References:}

1. Viddil statistiki Kosivs'koï rajonnoï derzhavnoï administraciï. URL: https://kosivrda.gov.ua/statystyka.html?start=300

2. Govorko, O. V. (2017). Efektivnist' sistemi zabezpechennja ohoroni zdorov'ja naselennja Ukraïni [The effectiveness of the health care system of the population of Ukraine]. Intelekt XXI Intelligence XXI, 2, 92-97 [in Ukrainian].

3. Karamishev, D. V. \& Udovichenko, N. M. (2008). Sutnist' rozuminnja efektivnosti upravlinnja sistemoju ohoroni zdorov'ja $\mathrm{v}$ suchasnih umovah [The essence of understanding the effectiveness of health care management in modern conditions]. Derzhavne budivnictvo - State building, 1, URL: http://nbuv.gov.ua/UJRN/DeBu_2008_1_26 [in Ukrainian].

4. Martinjuk, O. A. (2016). Vprovadzhennja sistemi upravlinnja jakistju v medichnih zakladah [Implementation of quality management system in medical institutions]. Prichornomors'ki ekonomichni studii - Black Sea Economic Studies, 6, 75-79 [in Ukrainian].

5. Mokric'ka, A.B. (2014). Finansove zabezpechennja ohoroni zdorov'ja Ukraïni: teoretichna konceptualizacija ta problemi organizaciï [Financial support of health care in Ukraine: theoretical conceptualization and problems of organization]. Nauka j ekonomika - Science and economics, 4 (36), 177-179 [in Ukrainian].

6. Nazarko, S. O. (2020). Efektivne upravlinnja medichnim zakladom v umovah reformuvannja sistemi ohoroni zdorov'ja [Effective management of a medical institution in terms of reforming the 
health care system]. Efektivna економіка - Effective Economics. URL: http://www.economy.nayka.com.ua/pdf/1_2020/57.pdf/ [in Ukrainian].

7. Panchishin, N. Ja. \& Smirnova, V. L. (2012) Ocinka efektivnosti upravlinnja v sistemi ohoroni zdorov'ja [Estimation of management efficiency in the health care system]. Visnik social'nö̈ gigicni ta organizaciï ohoroni zdorov'ja Ukraïni - Bulletin of social hygiene and health care organization of Ukraine, 3, 57-59 [in Ukrainian].

8. Publichnij zvit golovi Kosivs'koï rajonnoï derzhavnoï administraciï. URL: http://www.if.gov.ua/files/uploads/\%D0\%97\%D0\%B2\%D1\%96\%D1\%82\%202017\%20\%D0\%9A\%D 0\%BE\%D1\%81\%D1\%96\%D0\%B2\%D1\%81\%D1\%8C\%D0\%BA\%D0\%B0\%20\%D0\%A0\%D0\%94 $\%$ D0\%90.pdf.

9. Shveda, Ju. I. (2018).Vpliv konkurenciï na efektivnist' sistemi ohoroni zdorov'ja Ukraïni [The impact of competition on the efficiency of the health care system of Ukraine]. Efektivnist' derzhavnogo upravlinnja - Efficiency of public administration, 3, 169-180 [in Ukrainian].

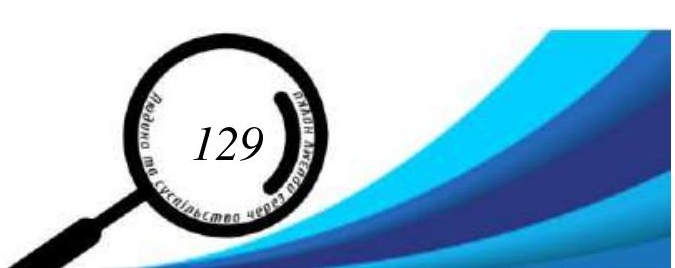

